\title{
COMPARATIVE ANALYSIS OF POPULATION MORTALITY IN THE CITIES OF SEVERODVINSK AND ARKHANGELSK
}

\author{
Saltykova MM凶, Bobrovnitskiy IP, Balakaeva AV
}

Centre for Strategic Planning and Management of Biomedical Health Risks of the Federal Medical Biological Agency

\begin{abstract}
Increasing use of ionizing radiation sources in different spheres of human life dictates the need for investigating the effects of low-dose radiation on mortality and morbidity. The aim of this study was to compare mortality from the most common non-communicable diseases in the cities of Severodvinsk and Arkhangelsk. We analyzed the rates of age- and sex-specific mortality from circulatory system diseases (CSD), malignancies, digestive system disorders, respiratory system diseases, and external causes. CSD-related mortality among men and women past working age was higher in Severodvinsk than in Arkhangelsk (median $\left(Q_{1} ; Q_{3}\right)$ : $3,349(3,271 ; 3,458)$ vs $2,651(2,618 ; 2,756), p<0.012 ; 1,947(1,890 ; 2,022)$ vs $1,753(1,727 ; 1,809), p<0.012 ; 292(281 ; 342)$ vs $265(253 ; 274), p<0.025$, respectively). For other causes of death, mortality rates in Severodvinsk did not exceed those in Arkhangelsk. Increased mortality from CSD in Severodvinsk cannot be linked to socioeconomic conditions or chemical air pollution because the standard of living is higher in Severodvinsk than in Arkhangelsk, whereas the level of chemical pollution is lower. At the same time, the presence of the nuclear shipyard and radioactive waste repository in Severodvinsk could cause chronic exposure to low-dose radiation. It is important to expand preventive measures aimed at early detection of vascular damage in nuclear workers and general groups of population residing in the vicinity of hazardous radiation sites.
\end{abstract}

Keywords: circulatory system diseases, risk factors, mortality

Funding: the study was part of the State Assignment (Research and Development Project AAAA-A19-119020890029-1)

Author contribution: Saltykova MM, Bobrovnitskiy IP — study concept and design; Saltykova MM, Balakaeva AV — data analysis and interpretation; Saltykova MM, Bobrovnitskiy IP, Balakaeva AV — manuscript preparation.

$\triangle$ Correspondence should be addressed: Marina M. Saltykova

Pogodinskaya, 10, str. 1, 119121, Moscow, Russia; saltykova@cspmz.ru

Received: 10.11.2021 Accepted: 29.11.2021 Published online: 20.12.2021

DOI: 10.47183/mes.2021.042

\section{СРАВНИТЕЛЬНЫЙ АНАЛИЗ СМЕРТНОСТИ НАСЕЛЕНИЯ В ГОРОДАХ СЕВЕРОДВИНСКЕ И АРХАНГЕЛЬСКЕ}

М. М. Салтыкова $\bowtie$, И. П. Бобровницкий, А.В.Балакаева

Центр стратегического планирования и управления медико-биологическими рисками здоровью Федерального медико-биологического агентства

\begin{abstract}
В связи с широким использованием источников ионизирующего излучения в разных сферах деятельности человека увеличивается число исследований, изучающих влияние облучения в малых дозах на заболеваемость и смертность населения. Целью данного исследования было провести сравнительный анализ смертности от основных неинфекционных заболеваний в городах Северодвинске и Архангельске. В анализ включили данные о возрастных коэффициентах смертности от болезней системы кровообращения (БСК), злокачественных новообразований, болезней органов пищеварения, болезней органов дыхания, а также от внешних причин. Показано, что в Северодвинске выше, чем в Архангельске, смертность от БСК мужчин и женщин в возрасте старше трудоспособного и мужчин в трудоспособном возрасте (медиана $\left(Q_{1} ; Q_{3}\right): 3349$ (3271; 3458$)$ против 2651 (2618; 2756$)$, p < 0,012; 1947 (1890; 2022) против 1753 (1727; 1809), p < 0,012; 292 (281; 342) против 265 (253; 274), p < 0,025 соответственно). Смертность в Северодвинске от других причин не превосходила соответствующие показатели в Архангельске. Повышенная смертность от БСК в Северодвинске не могла быть обусловлена социально-экономическими условиями или химическим загрязнением атмосферного воздуха, поскольку уровень жизни в Северодвинске выше, чем в Архангельске, а уровень химического загрязнения ниже. Вместе с тем, расположение в Северодвинске предприятий атомного судостроения и хранилища радиоактивных отходов потенциально могло обуславливать хроническое облучение в малых дозах части населения этого города. Необходимо расширение профилактических мероприятий, направленных на раннее выявление поражения кровеносных сосудов у лиц, работающих и проживающих в районах расположения радиационно-опасных объектов.
\end{abstract}

Ключевые слова: болезни системы кровообращения, факторы риска, смертность

Финансирование: работа выполнена в рамках государственного задания рег. № НИОКТР АААА-А19-119020890029-1

Вклад авторов: М. М. Салтыкова, И. П. Бобровницкий - концепция и дизайн исследования; М. М. Салтыкова, А. В. Балакаева - анализ и интерпретация данных; М. М. Салтыкова, И. П. Бобровницкий, А. В. Балакаева - написание и редактирование текста.

$\bowtie$ Для корреспонденции: Марина Михайловна Салтыкова

ул. Погодинская, д. 10, стр. 1, 119121, г. Москва, Россия; saltykova@cspmz.ru

Статья получена: 10.11.2021 Статья принята к печати: 29.11.2021 Опубликована онлайн: 20.12.2021

DOI: $10.47183 /$ mes.2021.042

Wide use of ionizing radiation sources in various industries and fields of human life dictates the need to research the effects of low-dose radiation on the risk of cardiovascular diseases, their exacerbation and the associated mortality [1-8]. The primary sources of ionizing radiation with the most significant effect on the human body include naturally occurring background radiation (cosmic rays from space, radionuclides in the Earth's crust and ambient air, etc.) and man-made radionuclides. Besides, medical equipment has made a considerable contribution to the total public exposure to radiation in the past decades. It is assumed that exposure to medical diagnostic and therapeutic technologies and modern nuclear technologies will be low-dose [4-8].

Today, the level of radiation safety at nuclear fuel cycle enterprices facilities satisfactory [9, 10]. However, only a few decades ago, communities residing in their vicinity could have been exposed to low doses of radiation over long periods of time. At the same time, organ damage is not directly caused 
Table 1. The level of chemical air pollution in Arkhangelsk and Severodvinsk in 2010-2018

\begin{tabular}{|l|c|c|c|c|c|c|c|c|c|}
\hline & 2010 & 2011 & 2012 & 2013 & 2014 & 2015 & 2016 & 2017 & 2018 \\
\hline AArkhangelsk & $\mathrm{H}$ & $\mathrm{H}$ & $\mathrm{H}$ & $\mathrm{H}$ & $\mathrm{I}$ & $\mathrm{I}$ & $\mathrm{I}$ & $\mathrm{L}$ & $\mathrm{I}$ \\
\hline Severodvinsk & $\mathrm{I}$ & $\mathrm{L}$ & $\mathrm{I}$ & $\mathrm{I}$ & $\mathrm{L}$ & $\mathrm{L}$ & $\mathrm{L}$ & $\mathrm{L}$ & $\mathrm{L}$ \\
\hline
\end{tabular}

Note. H - high (API: 7-13), I — increased (API: 5-6), L — low (API <5).

by ionizing radiation but is induced by free radicals generated by it [11-13].

The biological effects of such radiation are far milder than those associated with acute exposure owing to the compensatory mechanisms maintaining body functions under such conditions; diseases caused by ionizing radiation can manifest many years after exposure [6]. This raises the need for improved methodological approaches to health surveillance in the areas where hazardous radiation sites are located. Stratification by age will help to account for the impact of increased radioactive pollution in previous years or decades. One of the ways to make public health assessment more objective is to conduct comparative studies using data on mortality rates in cities with and without nuclear fuel cycle industries. The pairs of cities should be selected in such a way so as to exclude the confounding effects of environmental and socioeconomic factors.

The aim of this study was to compare mortality rate from the most common non-communicable diseases in Severodvinsk (population: 183,255 in 2018) and Arkhangelsk (population: 349, 742 in 2018). Severodvinsk is a monocity with a nuclear shipyard. Arkhangelsk is located in similar climatic conditions, 30 $\mathrm{km}$ away from Severodvinsk, and was chosen for comparison.

\section{METHODS}

We analyzed mortality rates from circulatory system diseases (CSD), malignant neoplasms (MN), digestive system diseases (DSD), respiratory system diseases (RSD), and external causes (EC) in different age groups using reports from 2011-2018 provided by the Federal State Statistics Service (Rosstat). The mortality rate was defined as the number of deaths per 100,000 population in a specified age and sex group. The analysis was done by quinary age groups (30-85 years), larger working-age groups (18-55 years for women and 18-60 yeas for men) and the group of individuals past working age.

In addition, we analyzed the Air Pollution Index (API), which characterizes ambient air pollution, using data from the Federal Service for Hydrometeorology and Environmental Monitoring (Gidromet) [14, 15], as well as migration data and socioeconomic indicators in the two cities using Rosstat data. The economic index (EI) was calculated based on Rosstat data to estimate the standard of living $[16,17]$. El was calculated as a mean ratio of the average monthly salary in each of the studied cities (this parameter is the most resistant to the impact of economic inequality [18]) to the subsistence minimum. To estimate population migration, the migration rate was calculated

as a ratio of net migration to the average annual population size in each of the cities using Rosstat data [16].

Statistical analysis was performed in STATISTICA 10.0 (StatSoft Inc.; USA). Median values were used as an indicator of the center of distribution for annual mortality values and other studied parameters; the lower and upper quartiles (Q1 and Q3) were used as a measure of intragroup spread. The two-sided Wilcoxon rank-sum test was performed to assess the statistical significance of differences in the studied parameters between the two cities. Differences were considered significant at $p$ (type l error rate) $<0.05$.

\section{RESULTS}

Table 1 illustrates the level of chemical air pollution in Arkhangelsk and Severodvinsk. In 2010-2018, the level of air pollution in Severodvinsk was lower than in Arkhangelsk. At the same time, the standard of living (El) was higher in Severodvinsk (3.95 (3.7-4.2) vs 3.3 (3.1-3.8) in Arkhangelsk).

The analysis of migration rates revealed the following patterns. For individuals over 60 years of age, the migration rate (per 10,000 of population in the analyzed age group) was significantly lower in Severodvinsk than in Arkhangelsk (-93 $(-108 ;-77)$ vs $-36(-44 ;-26)$ for women, $p=0.018 ;-104$ $(-123 ;-71)$ vs $-56(-60 ;-46)$ for men, $p=0.018)$. No differences were observed in the migration rate for the individuals aged 20-59 years (women: $-75(-90 ;-32)$ in Severodvinsk vs -29 $(-47 ;-16)$ in Arkhangelsk, $p=0.176$; men: $-46(-53 ;-40)$ in Severodvinsk vs $-36(-53 ;-26)$ in Arkhangelsk, $p=0.612)$. The negative migration rate suggests that more people were leaving both cities than coming to live in them.

Tables 2 and 4 show mortality rates for men; Tables 3 and 5 show mortality rates for women. Tables 2 and 3 contain data on different working-age groups. Tables 4 and 5 provide information on men and women past working age. Mortality was significantly higher in Severodvinsk for CSD only. Specifically, it was higher for working-age men and past working age men and women. A more detailed analysis of the quinary age groups revealed that mortality from CSD was significantly higher for both men and women over 65 years residing in Severodvinsk. At the same time, no significant differences in mortality rates were detected between the quinary age groups of working-age men and women: although median CSD mortality in the quinary age groups of working-age individuals was higher in Severodvinsk than in Arkhangelsk, the observed differences were insignificant due to interannual differences and small sample sizes (8 years,

Table 2. Rates of mortality from the leading causes of death among working-age men (per 100,000 population)

\begin{tabular}{|l|c|c|c|}
\hline & Mortality rates in Arkhangelsk Median $\left(Q_{1} ; Q_{3}\right)$ & Mortality rates in Severodvinsk Median $\left(Q_{1} ; Q_{3}\right)$ & $p$ \\
\hline CSD & $265(253 ; 274)$ & $292(281 ; 342)$ & 0,025 \\
\hline MN & $104(97 ; 108)$ & $101(95 ; 111)$ & 0,999 \\
\hline DSD & $52(48 ; 58)$ & $43(40 ; 50)$ & 0,207 \\
\hline RSD & $40(35 ; 44)$ & $29(27 ; 30)$ & 0,012 \\
\hline EC & $232(211 ; 251)$ & $202(199 ; 221)$ & 0,036 \\
\hline
\end{tabular}

Note. $Q_{1}$ and $Q_{3}$ are the lower and upper quartiles. 
Table 3. Rates of mortality from the leading causes of death among working-age women (per 100,000 population)

\begin{tabular}{|l|c|c|c|}
\hline & Mortality rates in Arkhangelsk Median $\left(Q_{1} ; Q_{3}\right)$ & Mortality rates in Severodvinsk $\left(Q_{1} ; Q_{3}\right)$ & $p$ \\
\hline CSD & $51(46 ; 55)$ & $63(55 ; 70)$ & 0,208 \\
\hline MN & $45(43 ; 49)$ & $48(45 ; 56)$ & 0,263 \\
\hline DSD & $21(20 ; 23)$ & $23(21 ; 29)$ & 0,400 \\
\hline RSD & $9(7 ; 14)$ & $7(5 ; 8)$ & 0,575 \\
\hline EC & $47(45 ; 52)$ & $43(37 ; 44)$ & 0,123 \\
\hline
\end{tabular}

2011-2018). Differences in CSD mortality were significant only when all age subgroups of working-age men were pooled.

The analysis of mortality in the working-age population associated with other causes of death (Tables 2 and 3) demonstrated that male mortality from RSD and external causes was significantly lower in Severodvinsk; no significant differences in cancer-related and DS-related male mortality were observed between the cities. Besides, no significant differences were found in the rates of mortality from the leading causes of death among working-age women.

The analysis of mortality among individuals past working age (Tables 4 and 5) showed that unlike CSD mortality, which was higher in Severodvinsk, both male and female mortality rate from the leading causes of death was significantly higher in Arkhangelsk. The exception was male mortality from DSD, for which no significant differences were observed. The analysis of mortality associated with cancer, DSD, RSD, and EC in quinary age groups revealed no stable patterns.

\section{DISCUSSION}

The analysis revealed that mortality from CSD among workingage men and past working age women and men was higher in Severodvinsk; for other causes of death, either no significant differences between the cities were established, or the mortality rate was higher in Arkhangelsk (specifically, mortality from other causes among men and women past working age, except for male mortality from DSD, and mortality from RSD and EC for working-age men).

Because the standard of living was higher and the outward migration of the population past working age was greater in Severodvinsk than in Arkhangelsk (it is only logical that people with chronic deseases will be among the first to leave cold climate regions), differences in the socioeconomic conditions could not be the underlying cause of increased mortality from CSD in Severodvinsk.
The fact that CSD-related mortality was higher in Severodvinsk for both men and women past working age suggests the important role of environmental as opposed to occupational health factors because there are more men working in hazardous industries than women. The level of chemical air pollution in Severodvinsk was lower than in Arkhangelsk but the environmental conditions and climate in these cities are the same. This leads us to hypothesize that increased mortality from CSD in individuals past working age residing in Severodvinsk may be associated with increased background radiation in the last decades of the 20th century and the first years of the 21st century due to environmental pollution with radioactive waste: at that time, Mironov mountain (JSC PO Sevmash), the repository for solid radioactive waste, could not provide the sufficient level of radiation safety [19].

This study demonstrates significant differences in CSDrelated mortality among working-age men between the two cities in the absence of differences in female mortality. This may indirectly indicate the role of occupational exposure to radiation. The absence of radiation emergencies at Severodvinsk nuclear facilities suggests that its nuclear workers and city dwellers were exposed to only low doses of ionizing radiation in the past. However, there are no published data on radiation monitoring in Russia before 2000, so it is impossible to infer the doses the population was exposed to at that time.

At the same time, our findings are consistent with the results of other studies. The prevalence of arterial hypertension and cerebrovascular diseases among nuclear workers is higher than across Russia in general [20,21], whereas cancer prevalence and cancer mortality are lower. Besides, the risk of hypertension (one of the main risk factors for CSD) is heightened in people occupationally exposed to ionizing radiation. A meta-analysis of studies investigating the effect of low radiation doses on mortality conducted in 9 industrially developed countries from 1990 to 2010 revealed that the main contribution to mortality associated with prolonged exposure to low-dose radiation is made by cancer and CSD, in equal proportions [22].

Table 4. Rates of mortality from the leading causes of death among men past working age (per 100,000 population)

\begin{tabular}{|l|c|c|c|}
\hline & Mortality rates in Arkhangelsk Median $\left(Q_{1} ; Q_{3}\right)$ & Mortality rates in Severodvinsk Median $\left(Q_{1} ; Q_{3}\right)$ & $p$ \\
\hline CSD & $2651(2618 ; 2756)$ & $3349(3271 ; 3458)$ & 0,012 \\
\hline MN & $1458(1432 ; 1510)$ & $1333(1181 ; 1377)$ & 0,025 \\
\hline DSD & $227(202 ; 267)$ & $243(234 ; 258)$ & 0,779 \\
\hline RSD & $328(266 ; 393)$ & $194(171 ; 213)$ & 0,012 \\
\hline EC & $370(350 ; 408)$ & $274(260 ; 303)$ & 0,017 \\
\hline
\end{tabular}

Table 5. Rates of mortality from the leading causes of death among women past working age (per 100,000 population)

\begin{tabular}{|l|c|c|c|}
\hline & Mortality rates in Arkhangelsk Median $\left(Q_{1} ; Q_{3}\right)$ & Mortality rates in Severodvinsk Median $\left(Q_{1} ; Q_{3}\right)$ & $p$ \\
\hline CSD & $1753(1727 ; 1809)$ & $1947(1890 ; 2022)$ & 0,012 \\
\hline MN & $610(598 ; 647)$ & $497(471 ; 515)$ & 0,012 \\
\hline DSD & $165(154 ; 169)$ & $121(118 ; 134)$ & 0,017 \\
\hline RSD & $98(90 ; 127)$ & $46(40 ; 49)$ & 0,012 \\
\hline EC & $116(110 ; 128)$ & $76(74 ; 81)$ & 0,012 \\
\hline
\end{tabular}


As demonstrated by multiple studies, low doses of radiation received over a long time period cause oxidative and nitrosative stress accompanied by increased lipid peroxidation [11-13]. Low-dose radiation does not cause specific radiationinduced disorders but instead stimulates non-cancer noncommunicable diseases, including cardiovascular disorders, that can manifest years after the exposure [6, 23, 24].

The main mechanism underlying CSD development following exposure to ionizing radiation involves damage to the blood vessel wall. Its inner layer, endothelium, participates in the regulation of vascular tone through synthesis and release of vasoactive compounds and is the most sensitive to radiation [11-13].

\section{CONCLUSIONS}

Experimental and epidemiological studies conducted in the past decades have shown that prolonged exposure to low- dose ionizing radiation induces CSD; the main mechanisms underlying the detrimental effect of radiation on the cardiovascular system is oxidative and nitrosative stress, which leads to endothelial dysfunction, arterial hypertension and atherosclerosis. These pathological processes may be implicated in high mortality from CSD in Severodvinsk. It is important to continue research into the causes of increased morbidity and mortality from CSD (which is the leading cause of death in Russia) and the effects of lowdose radiation on the health of nuclear workers and other populations residing in the vicinity of hazardous radiation sites. In order to prevent premature deaths and improve the quality of life, it would be helpful to expand prevention measures aimed at timely detection of vascular damage in individuals exposed to low doses of ionizing radiation over long periods of time or those living near hazardous radiation sites and to elucidate the potential routes of entry of radionuclides into the human body.

\section{References}

1. Drubay D, Caer-Lorho S, Laroche P, et al. Mortality from circulatory system diseases among french uranium miners: a nested casecontrol study. Radiat Res. 2015; 183 (5): 550-62.

2. Karpov AB, Semenova YuV, Takhauov RM, et al. The risk of acute myocardial infarction and arterial hypertension in a cohort of male employees of Siberian Group of Chemical Enterprises exposed to long-term irradiation. Health Phys. 2012; 103 (1): 15-23.

3. Zablotska LB, Little MP, Cornett RJ. Potential increased risk of ischemic heart disease mortality with significant dose fractionation in the Canadian Fluoroscopy Cohort Study. Am J Epidemiol. 2014; (1): 120-31.

4. Semenova YuV, Karpov AB, Tahauov RM, Borisova EG, Maksimov DE, Trivozhenko AB, i dr. Ocenka strukturno-funkcional'nyh izmenenij sosudistoj sistemy u lic, podvergavshihsja professional'nomu oblucheniju nizkoj intensivnosti. Medicinskaja radiologija radiacionnaja bezopasnost'. 2016; 61 (1): 34-40. Russian.

5. Semenova YuV, Tahauov RM, Karpov AB, Litvinenko TM, Kalinkin DE. Faktory riska i puti profilaktiki ostrogo infarkta miokarda u personala predprijatij atomnoj promyshlennosti. Kardiovaskuljarnaja terapija i profilaktika. 2011; 10 (1): 23-29. Russian.

6. Sherif A, Benhammuda M, Fares S, Oroszi TL. Cardiovascular Diseases and Radiations. Journal of Biosciences and Medicines. 2017; (5): 72-77.

7. Vrijheid M, Cardi E, Ashmore P, Auvinen A, Bae J-M, H Engel $\mathrm{H}$, et al. Mortality from diseases other than cancer following low doses of ionizing radiation: results from the 15-Country Study of nuclear industry workers. International Journal of Epidemiology. 2007; (36): 1126-35.

8. Gorskij Al, Chekin SYu, Maksjutov MA, Kashheev W, Kochergina EV, Tumanov KA. Radiacionno-jepidemiologicheskaja klassifikacija kompleksov boleznej sistemy krovoobrashhenija cheloveka, associirovannyh s ionizirujushhim oblucheniem v malyh dozah. Radiacija i risk. 2016; 25 (4): 20-30. Russian.

9. Linge II, Kryshev II, redaktory. Radiojekologicheskaja obstanovka $\checkmark$ regionah raspolozhenija predprijatij Rosatoma. M.: «SAM poligrafist», 2015; 296 s. Russian.

10. BuzinovRV, redaktor. Osostojaniisanitarno-jepidemiologicheskogo blagopoluchija naselenija v Arhangel'skoj oblasti v 2017 godu: gosudarstvennyj doklad. Arhangel'sk, 2018; 149 s. Russian.

11. Saroyan KV, Sytnik MV, Miller ES, Puchenkova OA, Soldatov VO, Gashevskaya AS, et al. Combination of Captopril and Darbepoetin Alfa Attenuate Radiation-Induced-Endothelial Dysfunction. Journal of International Pharmaceutical Research. 2019; 46 (4): 291-5.

12. Kumarathasan P, Vincent R, Blais E, Saravanamuthu A, Gupta P, Wyatt $\mathrm{H}$, et al. Cardiovascular changes in atherosclerotic ApoE-

deficient mice exposed to Co60 $(\gamma)$ radiation. PLoS One. 2013; 8 (6): e65486. DOI: 10.1371/journal.pone.0065486.

13. Tkachenko M N, Kocjuruba AV, Baziljuk OV, Talanov SA, Popereka GM, Senjuk O F, i dr. Sosudistaja reaktivnost' i metabolizm reaktivnyh form kisloroda i azota pri dejstvii nizkih doz radiacii. Radiacionnaja biologija. Radiojekologija. 2009; 49 (4): 462-72. Russian.

14. Sostojanie zagrjaznenija atmosfery v gorodah na territorii Rossii za 2014. Ezhegodnik. Sankt-Peterburg, 2015; 287 s. Russian.

15. Sostojanie zagrjaznenija atmosfery $\vee$ gorodah na territorii Rossii za 2018. Ezhegodnik. Sankt-Peterburg, 2019; 249 s. Russian.

16. Baza dannyh pokazatelej municipal'nyh obrazovanij. Dostupno po ssylke: https://www.gks.ru/dbscripts/munst (data obrashhenija: 01.06.2021). Russian.

17. Velichina prozhitochnogo minimuma. Dostupno po ssylke: https:// www.fedstat.ru/indicator/30957 (data obrashhenija 01.06.2021). Russian.

18. Andreev EM, Shkolnikov VM. Svjaz' mezhdu urovnjami smertnosti i jekonomicheskogo razvitija $v$ Rossii i ee regionah. Demograficheskoe obozrenie. 2018; 5 (1): 6-24. Russian.

19. lojnsh Al, Kozodubov AA, Markarov VG, Terentev VG, Chopornjak AB. Normativnoe pravovoe obespechenie bezopasnosti pri vyvode iz jekspluatacii jaderno- i radiacionno-opasnyh ob"ektov atomnogo flota Rossii. M.: Nauka, 2008; 204 s. Russian.

20. Tukov AR, Gneusheva GI, Suvorova YuV, Prohorova ON. Ocenka zdorov'ja lic, podlezhashhih periodicheskim medicinskim osmotram i uchastvujushhih $v$ razrabotke, sborke-razborke jadernyh boepripasov. Medicina jekstremal'nyh situacij. 2011; 4 (38): 14-22. Russian.

21. Tukov AR, Gneusheva GI, Suvorova YuV. Ocenka zabolevaemosti boleznjami organov krovoobrashhenija lic, rabotajushhih $\mathrm{V}$ Rossijskih Federal'nyh jadernyh centrah (1994-2008 gg.). Medicina jekstremal'nyh situacii. 2011; 2 (36): 11-16. Russian.

22. Little MP, Azizova TV, Bazyka D, Bouffler SD, Cardis E, Chekin S, et al. Systematic Review and Meta-analysis of Circulatory Disease from Exposure to Low-Level lonizing Radiation and Estimates of Potential Population Mortality Risks. Environ Health Perspect. 2012; 120: 1503-11.

23. Karpov AB, Semjonova YuV, Dubin W, Litvinenko TM, Kubat ॥, Tahauov RM. Risk razvitija arterial'noj gipertonii u personala Sibirskogo himicheskogo kombinata. Radiacionnaja biologija. Radiojekologija. 2008; 48 (4): 456-63. Russian.

24. Telkova IL. Osobennosti projavlenij serdechno-sosudistyh zabolevanij u likvidatorov posledstvij avarii na Chernobyl'skoj atomnoj jelektrostancii spustja 25 let. Kliniko-analiticheskij obzor Kardiovaskuljarnaja terapija i profilaktika. 2012; 11 (3): 62-69. Russian. 


\section{Литература}

1. Drubay D, Caer-Lorho S, Laroche P, et al. Mortality from circulatory system diseases among french uranium miners: a nested casecontrol study. Radiat Res. 2015; 183 (5): 550-62.

2. Karpov AB, Semenova YuV, Takhauov RM, et al. The risk of acute myocardial infarction and arterial hypertension in a cohort of male employees of Siberian Group of Chemical Enterprises exposed to long-term irradiation. Health Phys. 2012; 103 (1): 15-23.

3. Zablotska LB, Little MP, Cornett RJ. Potential increased risk of ischemic heart disease mortality with significant dose fractionation in the Canadian Fluoroscopy Cohort Study. Am J Epidemiol. 2014; (1): 120-31.

4. Семенова Ю. В., Карпов А. Б., Тахауов Р. М., Борисова Е. Г., Максимов Д. Е., Тривоженко А. Б. и др. Оценка структурнофункциональных изменений сосудистой системы у лиц, подвергавшихся профессиональному облучению низкой интенсивности. Медицинская радиология и радиационная безопасность. 2016; 61 (1): 34-40.

5. Семенова Ю. В., Тахауов Р. М., Карпов А. Б., Литвиненко Т. М., Калинкин Д. Е. Факторы риска и пути профилактики острого инфаркта миокарда у персонала предприятий атомной промышленности. Кардиоваскулярная терапия и просиллактика. 2011; 10 (1): 23-29.

6. Sherif A, Benhammuda M, Fares S, Oroszi TL. Cardiovascular Diseases and Radiations. Journal of Biosciences and Medicines. 2017; (5): 72-77.

7. Vrijheid M, Cardi E, Ashmore P, Auvinen A, Bae J-M, H Engel $\mathrm{H}$, et al. Mortality from diseases other than cancer following low doses of ionizing radiation: results from the 15-Country Study of nuclear industry workers. International Journal of Epidemiology. 2007; (36): 1126-35.

8. Горский А. И., Чекин С. Ю., Максютов М. А., Кащеев В. В., Кочергина Е. В., Туманов К. А. Радиационноэпидемиологическая классификация комплексов болезней системы кровообращения человека, ассоциированных с ионизирующим облучением в малых дозах. Радиация и риск. 2016; 25 (4): 20-30.

9. Линге И. И., Крышев И. И., редакторы. Радиоэкологическая обстановка в регионах расположения предприятий Росатома. М.: «САМ полиграфист», 2015; 296 с.

10. Бузинов Р. В., редактор. О состоянии санитарноэпидемиологического благополучия населения в Архангельской области в 2017 году: государственный доклад. Архангельск, 2018; 149 c.

11. Saroyan KV, Sytnik MV, Miller ES, Puchenkova OA, Soldatov VO, Gashevskaya AS, et al. Combination of Captopril and Darbepoetin Alfa Attenuate Radiation-Induced-Endothelial Dysfunction. Journal of International Pharmaceutical Research. 2019; 46 (4): 291-5.

12. Kumarathasan $P$, Vincent $R$, Blais E, Saravanamuthu A, Gupta $P$, Wyatt $\mathrm{H}$, et al. Cardiovascular changes in atherosclerotic ApoE- deficient mice exposed to Co60 ( $\gamma$ radiation. PLoS One. 2013; 8 (6): e65486. DOI: 10.1371/journal.pone.0065486.

13. Ткаченко М. Н., Коцюруба А. В., Базилюк О. В., Таланов С. А. Поперека Г. М., Сенюк О. Ф. и др. Сосудистая реактивность и метаболизм реактивных форм кислорода и азота при действии низких доз радиации. Радиационная биология. Радиоэкология. 2009; 49 (4): 462-72.

14. Состояние загрязнения атмосферы в городах на территории России за 2014. Ежегодник. Санкт-Петербург, 2015; 287 с.

15. Состояние загрязнения атмоссреры в городах на территории России за 2018. Ежегодник. Санкт-Петербург, 2019; 249 с.

16. База данных показателей муниципальных образований. Доступно по ссылке: https://www.gks.ru/dbscripts/munst (дата обращения: 01.06.2021).

17. Величина прожиточного минимума. Доступно по ссылке: https://www.fedstat.ru/indicator/30957 (дата обращения 01.06.2021).

18. Андреев Е. М., Школьников В. М. Связь между уровнями смертности и экономического развития в России и ее регионах. Демографическое обозрение. 2018; 5 (1): 6-24.

19. Иойрыш А. И., Козодубов А. А., Маркаров В. Г., Терентьев В. Г., Чопорняк А. Б. Нормативное правовое обеспечение безопасности при выводе из эксплуатации ядерно- и радиационно-опасных объектов атомного флота России. М.: Наука, 2008; 204 c.

20. Туков А. Р., Гнеушева Г. И., Суворова Ю. В., Прохорова О. Н. Оценка здоровья лиц, подлежащих периодическим медицинским осмотрам и участвующих в разработке, сборкеразборке ядерных боеприпасов. Медицина экстремальных ситуаций. 2011; 4 (38): 14-22.

21. Туков А. Р., Гнеушева Г. И., Суворова Ю. В. Оценка заболеваемости болезнями органов кровообращения лиц, работающих в Российских Федеральных ядерных центрах (1994-2008 гг.). Медицина экстремальных ситуаций. 2011; 2 (36): 11-16.

22. Little MP, Azizova TV, Bazyka D, Bouffler SD, Cardis E, Chekin S, et al. Systematic Review and Meta-analysis of Circulatory Disease from Exposure to Low-Level lonizing Radiation and Estimates of Potential Population Mortality Risks. Environ Health Perspect. 2012; 120: 1503-11.

23. Карпов А. Б., Семёнова Ю. В., Дубин В. В., Литвиненко Т. М., Кубат И. И., Тахауов Р. М. Риск развития артериальной гипертонии у персонала Сибирского химического комбината. Радиационная биология. Радиоэкология. 2008; 48 (4): $456-$ 63.

24. Телкова И. Л. Особенности проявлений сердечно-сосудистых заболеваний у ликвидаторов последствий аварии на Чернобыльской атомной электростанции спустя 25 лет. Клинико-аналитический обзор. Кардиоваскулярная терапия и профилактика. 2012; 11 (3): 62-69. 